\title{
CORPVS VASORVM ANTIQVORVM
}

UNITED STATES OF AMERICA - FASCICULE 18

The Los Angeles County Museum of Art,

Fascicule I 



\section{CORPVS VASORVM ANTIQVORVM}

THE LOS ANGELES COUNTY MUSEUM OF ART

PAMELA M. PACKARD

and

PAUL A. CLEMENT

UNIVERSITY OF CALIFORNIA PRESS

BERKELEY - LOS ANGELES - LONDON

1977

The Los Angeles County Museum of Art Los Angeles $\cdot$ California

FASCICULE 1 - [U.S.A. FASCICULE 18] 
Corpus Vasorum Antiquorum (The Los Angeles County Museum of Art Fascicule 1)

is sponsored in part by the Samuel H. Kress Foundation

\author{
University of California Press \\ Berkeley and Los Angeles, California \\ University of California Press, Ltd. \\ London, England
}

ISBN 0-520-02850-3

Library of Congress Catalog Card Number: 74-84142

Copyright 01977 by The Regents of the University of California

ALL RIGHTS RESERVED

Printed in the United States of America

by The Stinehour Press, Lunenburg, Vermont

This book has been composed in Monotype Bembo

Illustrations printed by The Meriden Gravure Company

Meriden, Connecticut 